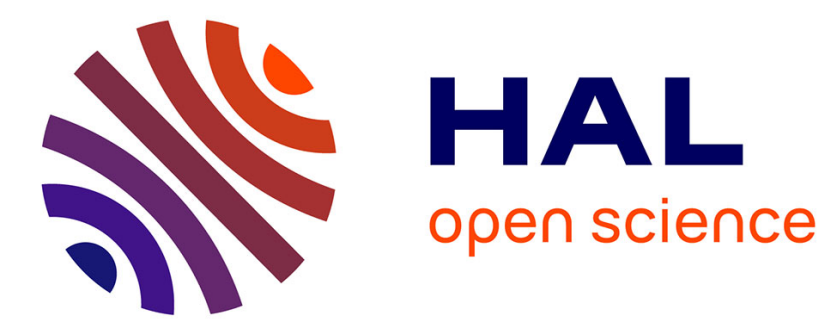

\title{
The communication of first-person thoughts
}

François Recanati

\section{To cite this version:}

François Recanati. The communication of first-person thoughts. Petr Kotatko, John Biro. Sense and Reference One Hundred Years After, Kluwer Academic Publisher, pp.95-102, 1995. ijn_00000301

\section{HAL Id: ijn_00000301 https://hal.science/ijn_00000301}

Submitted on 12 Nov 2002

HAL is a multi-disciplinary open access archive for the deposit and dissemination of scientific research documents, whether they are published or not. The documents may come from teaching and research institutions in France or abroad, or from public or private research centers.
L'archive ouverte pluridisciplinaire HAL, est destinée au dépôt et à la diffusion de documents scientifiques de niveau recherche, publiés ou non, émanant des établissements d'enseignement et de recherche français ou étrangers, des laboratoires publics ou privés. 
François Recanati

CREA

1 rue Descartes

75005 Paris, France

\section{The communication of first person thoughts}

In his article 'The Thought', Frege writes:

Every one is presented to himself in a particular and primitive way, in which he is presented to no one else. So, when Dr. Lauben thinks that he has been wounded, he will probably take as a basis this primitive way in which he is presented to himself. And only Dr. Lauben himself can grasp thoughts determined in this way. But now he may want to communicate with others. $\mathrm{He}$ cannot communicate a thought which he alone can grasp. Therefore, if he now says 'I have been wounded', he must use the 'I' in a sense which can be grasped by others, perhaps in the sense of 'he who is speaking to you at this moment'... (Frege 1918-19:25-6)

From this passage, two important ideas can be extracted. The first one is commonly accepted nowadays:

(a) First person thoughts concerning a person A can be grasped or entertained only by A. Another person, B, can entertain thoughts about A, but not first person thoughts about A: only A can think of himself in the first person. To be sure, B can also entertain first person thoughts; but these thoughts will be about B, not about A. (Even if B falsely believes that he is A, that would not make his first person thoughts thoughts about A.)

Once we accept (a), a problem arises, which I call 'the paradox of the first person'. First person thoughts are private, hence incommunicable; yet we do communicate them, by 
uttering first person sentences. How do we manage to do this? Frege's second idea is meant to solve the paradox:

(b) There are two sorts of senses or modes of presentation associated with the first person. Let us call the 'special and primitive' mode of presentation which occurs in first person thoughts 'Ego' or rather 'Ego ${ }_{x}$ ' where 'x' stands for the name of the

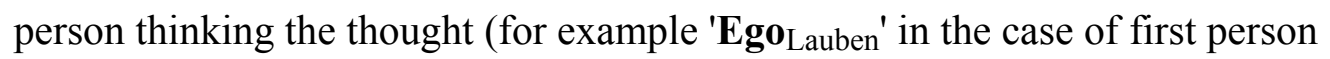
thoughts about Lauben). ${ }^{1}$ This mode of presentation must be distinguished from the mode of presentation associated with the word 'I' in communication ('he who is speaking to you at this moment'). The latter can be grasped by others, the former cannot.

The paradox is solved because, according to Frege, we do not communicate the original, incommunicable first person thought involving the mode of presentation Ego $_{\mathrm{x}}$, but a different thought involving the other sort of mode of presentation.

One might think (and some have said) that the distinction between the two modes of presentation is ad hoc and designed only to solve a particular problem. I, on the contrary, think it is an essential distinction - one which lies at the very foundation of the theory of language use. In earlier writings (Recanati 1990, 1993) I have drawn a similar distinction on quite independent grounds. The mode of presentation 'he who is speaking to you at this moment' - technically, 'the utterer of this token' — closely corresponds to the conventional meaning of 'I' (at least if the token-reflexive analysis of indexicals is correct), yet it is clearly distinct from the mode of presentation that occurs in our first person thoughts, i.e. the special and primitive way in which every one is presented to himself. ${ }^{2}$ This distinction between what I called 'linguistic' and 'psychological' modes of presentation is general (it affects every indexical, not merely 'I') and it holds whether or not we like Frege's solution to the paradox of the first person.

Even though it is far from ad hoc, Frege's solution is not altogether satisfactory, for it is sketchy and incomplete. What is the relation between the two sorts of mode of presentation mentioned in (b)? What makes it possible for the intersubjective sense associated with 'I' in communication to stand for the private sense $\mathbf{E g o}_{\mathrm{x}}$ which cannot be directly communicated? These are important questions which Frege does not address, let alone answer.

1 This notation is Peacocke's. See Peacocke 1981, 1983.

2 This is demonstrated, inter alia, by the fact that the utterer of a token might not realize that he (he himself*, as Castañeda would say) is the utterer of this token. To be sure, such a situation would be quite extraordinary, but it is by no means impossible. 
There is another solution to the paradox, which does not rely on the distinction between the two sorts of mode of presentation but on another distinction (Dummett 1981: 122-3). The speaker's first person thought is not, and cannot be, 'communicated' because the hearer does not, and could not, come to entertain that very thought as a result of the communication process. Still, it may be argued, the speaker's first person thought which is expressed by the utterance 'I have been wounded' can be recognized as such by the hearer. Even if the speaker's thought is unavailable to the hearer, the utterance may inform the hearer that the speaker entertains a certain type of thought, which he himself (the hearer) is unable to entertain. The speaker who says 'I have been wounded' expresses a first person thought, to the effect that he himself has been wounded. The hearer, upon understanding the utterance, can only form a different thought: 'He has been wounded'. Unlike the speaker, the hearer does not think of the referent (i.e. the speaker) in a first person way. So the speaker's thought has not been 'communicated' in the strong sense of the term. Yet it has been communicated in a weaker sense: Leo Peter knows which thought Lauben has expressed in saying 'I have been wounded'. Along these lines, it may be found unnecessary to distinguish between two sorts of thought, that which Lauben privately entertains and that which he communicates. To account for the communication of first person thoughts despite the 'incommunicability' of the latter one needs only to draw a distinction between two forms of communication: an utterance can 'express' a thought (weak communication) even if that thought is not thereby made available to the hearer (strong communication).

My primary aim in this paper is to fill the gap in Frege's account so as to make it satisfactory. But I will start by considering the alternative account and raising an objection to it. To meet the objection I will suggest an improvement of the alternative account which makes it indistinguishable from Frege's. The problem of the relation between the two modes of presentation will be solved along the way.

\section{2}

Even though is departs from Frege's own solution, the alternative account is Fregean in spirit. From a Fregean point of view, it has the great merit of allowing one to maintain the equation of thought and semantic content.

The semantic content of an utterance - that which the utterance expresses and which must be grasped for it to be correctly understood - is by definition an 'objective' property of that utterance which can be recognized by both speaker and hearer and which remains stable in the process of communication; but the required stability cannot be found at the level of thoughts, or so it seems. The first person thought which the speaker expresses by saying 'I have been wounded' differs from the hearer's thought formed upon understanding the utterance - they involve different modes of presentation of Lauben. The sentence means the same thing for speaker and hearer, and the statement that is made — to the effect that Lauben has been wounded — is also the 
same for both, but the associated thoughts change as communication proceeds from speaker to hearer. This is what makes the Russellian notion of a (singular) 'proposition' an arguably better candidate for the status of semantic content than the Fregean notion of a thought. For the proposition ('what is said', the 'statement' that is made) remains constant from one person to the next, in contrast to the thought. As John Perry says, 'one reason we need singular propositions is to get at what we seek to preserve when we communicate with those who are in different contexts' (Perry 1988: 4).

The alternative account disposes of this objection to Frege's equation of thought and semantic content. Even though the speaker's thought is tied to his own point of view and cannot be entertained by someone else (e.g. the hearer), still, it is this thought which is expressed by the utterance and can be recognized as such by the hearer. Its being publicly recognizable confers a sufficient objectivity on the speaker's thought, despite its essential subjectivity, to make it a plausible candidate for the status of semantic content.

Let us analyse the theoretical move at work here. Two points of view are involved in the communication process: that of the speaker and that of the hearer. In Frege's example the speaker's thought includes the mode of presentation $\mathbf{E g o}_{\mathrm{x}}$, while the hearer's thought, formed upon understanding the utterance, is a demonstrative, third person thought: 'He has been wounded'. As long as the speaker's thought is seen as on the same footing as the hearer's, it is tied to a particular point of view and lacks the sort of objectivity needed to equate it with the utterance's semantic content. The move consists in privileging the speaker's thought and giving primacy to his point of view over the hearer's. On the 'alternative account' I have sketched (following Dummett), it is the speaker's first person thought rather than the hearer's which is objectively 'expressed' by the utterance and recognized as such by all participants in the speech episode.

One possible objection to this move is that it is somehow arbitrary. How do we choose the particular point of view to be privileged? On intuitive grounds it seems natural to select the point of view of the speaker, yet there are also reasons to select the hearer's point of view. As Evans emphasized, what matters, when we want to individuate semantic content, is what would count as a proper understanding of an utterance (Evans 1982: 92, 143n, 171, etc.); but 'understanding' defines the task of the hearer. Thus it is the hearer's point of view which Evans privileges. As a result of that choice he is led to deny that 'I' expresses the concept Ego $\mathbf{g}_{\mathrm{x}}$ : according to him, 'I' expresses a demonstrative concept akin to that expressed by the demonstrative phrase 'that person'.

To overcome the difficulty, one may try a slightly different route. Instead of privileging a particular point of view (that of the speaker or that of the hearer), we may decide to focus on what is common to both points of view. This more or less corresponds to the Russellian strategy. According to the Russellian, what is common to 
the speaker's thought that he himself has been wounded and to the hearer's thought that that man, Lauben, has been wounded, is the singular proposition: <Lauben, the property of having been wounded $>$, that is, the state of affairs which both thoughts represent (their common 'incremental truth-conditions', in Perry's terminology [Perry 1990]). Now this commonalist strategy can also be opted for in a Fregean framework, for there is more that is common to both thoughts than merely the state of affairs they represent at the level of 'incremental truth-conditions'. In particular, there is more that is common to the modes of presentation under which Lauben and his addressee respectively think of Lauben than merely the reference, i.e. what these modes of presentation are modes of presentation of.

Most authors in the field, whether Russellian or Fregean, draw a distinction between descriptive and nondescriptive modes of presentation. Indexicals and proper names typically express nondescriptive modes of presentation, in contrast to (attributively used) definite descriptions, which express descriptive modes of presentation. ${ }^{3}$

What are nondescriptive modes of presentation? Like a number of contemporary authors, I construe 'nondescriptive' modes of presentation as dossiers of information.

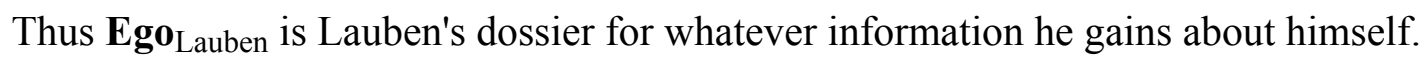
What is 'special and primitive' about this sort of dossier is that Lauben - like all of us - has a particular way of acquiring information about himself, such that (i) only Lauben can acquire information about Lauben in this way, and (ii) Lauben can acquire information in this way only about Lauben. An 'Ego'-dossier serves as repository for information gained in this particular way (the first person way).

Qua dossier, a nondescriptive mode of presentation contains information about whatever the dossier concerns. This allows for the following possibility: two dossiers which differ by their global content and/or by the sort of dossier they are may nevertheless have something in common, namely part of their content — some particular piece of information which they both contain. This is what happens in Frege's example. Both the thought of the speaker and that of the hearer include a mode of presentation which corresponds to their dossier concerning Lauben. The modes of presentation in question are quite different from each other: the speaker's is a first person mode of presentation (i.e. it corresponds to a dossier based on the special way of acquiring information mentioned above) while the hearer's is a third person mode of presentation. Nor do they contain the same information: there are things which Lauben knows about Lauben which his hearer does not know, and the other way round. But there are also pieces of information which both dossiers contain — there are things

\footnotetext{
3 The modes of presentation in question, whether descriptive or nondescriptive, are all 'psychological' modes of presentation in the sense of section 1 .
} 
which both Lauben and his hearer know about Lauben. The latter provide identificatory facts which Lauben and his hearer can appeal to in order to secure reference when communicating about Lauben. In particular, both Lauben's and his hearer's dossier concerning Lauben include the information that Lauben is the utterer of this token of 'I have been wounded'. That is part of Lauben's current notion of himself as much as it is part of his hearer's current notion of Lauben: Lauben is conscious of being the utterer, and the hearer also knows that Lauben is the utterer, the man speaking to him at this moment. That information is part of both dossiers, even though one is a first person dossier and the other a third person dossier. Now that specific aspect common to both the speaker's and the hearer's notion of the reference is, I suggest, what is expressed by the linguistic expression ' $I$ '. The reference of ' $I$ ' is presented as being the utterer of this token (linguistic mode of presentation). That linguistic mode of presentation is intersubjective, unlike the psychological mode of presentation which is subjective (i.e. the notion of himself, on the speaker's side, or the notion of that man, on the hearer's side); but the former may be construed as an aspect or part of the latter, an aspect (or part) which is common to the speaker's and the hearer's point of view.

Note that the identificatory fact which Lauben appeals to in order to secure reference to himself in communication belongs to a special category of identificatory facts: the category of communication-specific identificatory facts. Those facts do not exist independently of communication but are created in the very process of communication (Benveniste 1956). They are aspects of the speech situation, and as such they are automatically (and mutually) known to both speaker and hearer qua participants in that situation. Thus both the speaker and the hearer (in a normal conversational setting) know that the speaker - say Lauben — is the speaker, that the hearer - say, Leo Peter - is the hearer, and so forth. This enables the speaker to use these mutually manifest facts in referring to the speaker, the hearer and other aspects of the speech situation. Indexicals are conventional means of doing so: the linguistic modes of presentation conventionally expressed by indexicals such as 'I' or 'you' ('the utterer', 'the addressee') correspond to facts about their referents which are created by the speech situation itself and are therefore mutually manifest to participants in the speech situation.

Since the identificatory fact appealed to by virtue of the linguistic sense of the indexical is mutually known to the speaker and his hearer, it belongs to their respective dossiers concerning the reference - the speaker's first person dossier and the hearer's third person dossier. The linguistic sense of the indexical can therefore stand for both dossiers through a cognitive process of 'synecdoche' (Recanati 1993): the part stands for the whole. The linguistic sense of 'I' ('the utterer of this token') stands for the speaker's notion of himself because it corresponds to an aspect of that notion, to some information which the speaker's Ego-dossier contains (the information that he is the utterer of this token). Interpreting the utterance - the hearer's task — consists in going 
back from the part to the whole; but it is not the same whole at both ends of the communicative process. We start with the speaker's thought which involves his first person dossier. The latter does not go into the semantic content of the utterance, which contains only the linguistic sense of 'I', corresponding to an aspect or part of the original dossier. At the other end we find the hearer's thought, formed by 'interpreting' the utterance's semantic content and somehow enriching it with the hearer's own dossier concerning the speaker, which dossier also contains as a component part the identificatory fact appealed to by the indexical.

On this view Frege was right: that which is communicated - the utterance's semantic content - is not quite the speaker's original thought. It involves a mode of presentation ('the utterer of this token') which is closely related to the linguistic meaning of 'I' and differs from the special and primitive mode of presentation $\mathbf{E g o}_{\mathrm{x}}$ which occurs in the speaker's first person thought that he himself has been wounded.

\section{References}

Benveniste, E., 1956: La nature des pronoms. Reprinted in his Problèmes de linguistique générale, Paris: Gallimard (1966), 251-7.

Dummett, M., 1981: The Interpretation of Frege's Philosophy. London: Duckworth. Evans, G., 1982: The Varieties of Reference (J. McDowell ed.). Oxford: Clarendon Press.

Frege, G., 1918-19: The Thought: a Logical Enquiry. English trans. by A. and M.

Quinton in P. Strawson (ed.), Philosophical Logic, Oxford University Press (1967), 17-38.

Peacocke, C., 1981: Demonstrative Thoughts and Psychological Explanation. Synthese 49: $187-217$.

Peacocke, C., 1983: Sense and Content. Oxford: Clarendon Press.

Perry, J., 1988: Cognitive Significance and New Theories of Reference. Noûs 22: 1-18. Perry, J., 1990: Individuals in Informational and Intentional Content. In E. Villanueva (ed.), Information, Semantics and Epistemology, Oxford: Basil Blackwell, 172-189.

Recanati, F., 1990: Direct Reference, Meaning, and Thought. Noûs 24: 697-722.

Recanati, F., 1993: Direct Reference: From Language to Thought. Oxford: Basil Blackwell. 